\section{Social Life, Economic Status and Health care Delivery Practices of the People of Bede Community of Bangladesh: A Case Study}

\author{
Mohammad Taleb Hossain ${ }^{1}$, Md. Mosharaf Hossain Miazi ${ }^{1}$, Abdul \\ Ghani $^{2}$ \\ Department of Pharmacy, Northern University Bangladesh ${ }^{1}$ \\ Department of Pharmacy, Stamford University Bangladesh ${ }^{2}$
}

\author{
*Corresponding Author \\ Mohammad Taleb Hossain \\ Assistant Professor \\ Department of Pharmacy \\ Northern University Bangladesh \\ Contact No.: +8801716499889 \\ E-mail: talimmsavar@yahoo.com
}

Received- 1 December, 2009

Accepted for Publication- 20 December, 2009

\begin{abstract}
This study was conducted to observe the socio-economical status, living standard and health management practices of the people of the Bede community of Bangladesh. Bedes living in the Savar area of Dhaka district was selected for a case study. To conduct the study, data were obtained through a questionnairebased survey of 700 respondents about their social and economical status, professional practices, standard of living and literacy status, health management and treatment methods used. It has been observed that these mostly nomadic people of the Bede community have a weak socio-economic condition, large family size $\{\{9-16$ member family (58.22\%); 17-24 member family $(22.20 \%)\}$, intense smoking habit and a low level of literacy $(80.00 \%$ people are illiterate). They practice ethno-medicine and snake-charming as their main professional business to earn a living. In offering health care services to people, they use medicaments prepared from various plant and animal parts and minerals and apply various ethno-treatment techniques, like spiritual, physical, mystical and psychological techniques to treat various ailments. Although they practice their age-old traditional system of medicine as their profession to treat others, they have been found to depend largely on Allopathic, Homeopathic and modern Traditional medicines for treating their own illness, particularly when they suffer from diarrhoea, dysentery, small pox, orthopedic problems, and even snake-bite, which is supposed to be their own specialty. Bedes live below the poverty line.
\end{abstract}

Key words: Bede community, Social life, Health practices, Economic status

\title{
INTRODUCTION
}

Bedes, a marginalized Muslim community of Bangladesh, are also known as 'Water gypsy' or 'River gypsy' in Bangladesh; 'Montong tribe' in Myanmar and 'Bedouin' in Arab countries. They mostly live a nomadic life, moving from place to place to earn a living. An estimated 0.5 million nomadic Bedes live in Bangladesh (Maksud, 2006; Beurden, 2007). Every year Bedes come in groups to gather in about 65 different areas of Bangladesh and on an average each group lives 2 months in any particular area except those living on the land (Maksud, 2002). Many Bede people live in Savar area, 15 Kilometer away from the capital city Dhaka, round the year. Due to a weak socio-economic condition Bedes are to depend mostly on traditional ethno-medicine practice. This group of people also practices various other professions like snake-charming, magic-showing, snake-selling, spiritual healing, etc, for their livelihood.

\section{MATERIALS AND METHODS}

To conduct the study an extensive questionnaire-based survey was carried out upon 700 respondents out of a total of 7500 Bede people of Bangladesh. In order to assess the standard of their social life and socio-economic condition, parameters like age, sex, family size, educational status, income level, sources of income, etc., were studied by direct personal interaction with the people of the study group and information obtained from other relevant sources. Some other parameters including type and number of dwelling places, status of drinking water, sanitation system, addiction habit, family planning practice, vaccinations and recreation facilities were taken into consideration in this study. Types and methods of treatment practiced, used and received by the Bedes for management of health problems were also observed during this survey work. For this study, diseases were classified as simple and complicated and the nature of Bede treatment 
system and methods of preparation and application of the medicaments used for these diseases were investigated.

\section{RESULTS}

The survey revealed that the economic condition of the Bede community is very weak. Average monthly income of most Bede families (61.6\%) is less than BDT 3000.00 . 16.0\% families earn BDT $3000.00-5000.00$ and only $4.9 \%$. families earn more than BDT 5000.00. Major source of their earning is traditional healing (88.4\%) practice. Other sources include business $(7.6 \%)$ and service $(4.0 \%)$. Bedes are fond of living in large joint families. Their family sizes range from 1-4 members (4.9\%), 5-8 members (15.1\%), 9-16 members $(52.2 \%)$ to $17-24$ members $(22.2 \%)$. Illiteracy was found to be prominent among the Bede communities. Among the literate people, only $2.7 \%$ passed SSC, HSC and rarely above, $18.1 \%$ read from Class $\mathrm{V}$ to $\mathrm{X}$ and the rest are just literate. Bedes usually live in small boats $(24 \%)$, huts $(25 \%)$, kacha houses $(25.33 \%)$, and semi pacca $(17.32 \%)$ and pacca houses (9\%). Bedes are aware of birth control measures, but only $13 \%$ males and $60 \%$ females used birth control measures for family planning. Rest of them don't control birth, which accounts for their bigger family size (Table -1). Bedes have limited scope for recreation. They use radio \& record player $(24 \%)$, TV, radio \& record player $(81 \%)$ for their recreation. About $31 \%$ do not have any means of recreation and no one has internet facilities. These results have been presented in the following tables (Table-1 and Table-2a). Smoking habit among the males and females are $12.9 \%$ and $14.2 \%$ respectively. Post toilet hand washing by soap $32 \%$, and ash/mud $44 \%$. Latrines used are pacca $(20.4 \%)$, kacha $(33.3 \%)$, semi pacca $(26.7 \%)$ and sanitation less $(19.4 \%)$. They use tube-well (72\%) and tap water (4.9\%) for drinking) and rest of the people use water from other sources. (cf. Table $2 b$ ).

As evident from Table-3a, it was found that some common health complications among the Bede people are cold \& cough, fever, dysentery, diarrhoea, syphilis \& gonorrhea, leucoderma, jaundice and minor orthopedic problems. For the management of these diseases they use allopathic system for maximum cases. Also they use other systems of treatment. The features of the percentage of the treatment system used are tabulated in the Table 3a.

Table-1: Social structure and socio-economic condition of the Bedes

\begin{tabular}{|c|c|c|c|c|c|c|c|c|c|c|c|c|c|c|c|c|c|c|c|}
\hline \multicolumn{2}{|c|}{ Sex } & \multicolumn{5}{|c|}{ Age } & \multicolumn{4}{|c|}{ Family size } & \multicolumn{3}{|c|}{ Education } & \multicolumn{3}{|c|}{$\begin{array}{l}\text { Monthly } \\
\text { income }\end{array}$} & \multicolumn{3}{|c|}{ Income source } \\
\hline$\frac{\frac{0}{\pi}}{\sum}$ & 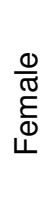 & $\frac{0}{6}$ & $\frac{\stackrel{N}{T}}{\leftarrow}$ & 号 & $\frac{P}{\frac{1}{10}}$ & $\stackrel{+}{\circ}$ & $\stackrel{+}{i}$ & $\begin{array}{l}\infty \\
\text { ம் }\end{array}$ & $\frac{\varphi}{\circ}$ & 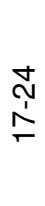 & 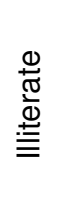 & $\begin{array}{l}0 \\
0 \\
\frac{0}{0} \\
0 \\
\frac{1}{0} \\
0 \\
\frac{\pi}{0} \\
0\end{array}$ & 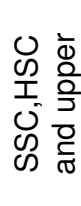 & $\begin{array}{l}\dot{8} \\
\circ \\
\llcorner \\
\circ \\
0\end{array}$ & 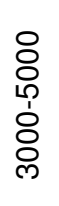 & 㕝 & 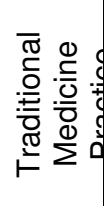 & $\begin{array}{l}\mathscr{D} \\
\stackrel{0}{2} \\
0 \\
\infty\end{array}$ & 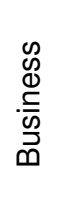 \\
\hline \multicolumn{2}{|c|}{$\circ$} & \multicolumn{5}{|c|}{$\circ^{\circ}$} & \multicolumn{4}{|c|}{$\circ$} & \multicolumn{3}{|c|}{$\circ^{\circ}$} & \multicolumn{3}{|c|}{$\circ^{\circ}$} & \multicolumn{3}{|c|}{$\circ$} \\
\hline $\begin{array}{l}\text { ले } \\
\text { \&े }\end{array}$ & $\begin{array}{l}\stackrel{P}{1} \\
\text { \& }\end{array}$ & $\underset{+}{\stackrel{+}{0}}$ & $\begin{array}{l}\stackrel{\infty}{\infty} \\
\dot{\sim}\end{array}$ & $\begin{array}{l}\stackrel{P}{0} \\
\text { î }\end{array}$ & $\begin{array}{l}\text { \& } \\
\stackrel{\text { ¿े }}{ }\end{array}$ & $\stackrel{8}{\stackrel{\leftrightarrow}{\wedge}}$ & 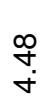 & $\begin{array}{l}\text { 움 } \\
\stackrel{i}{\circ}\end{array}$ & $\begin{array}{l}\text { Ñ } \\
\infty \\
\sim \\
\sim\end{array}$ & $\begin{array}{l}\stackrel{N}{N} \\
\stackrel{\text { N}}{ }\end{array}$ & $\begin{array}{l}8 \\
\varnothing \\
\infty\end{array}$ & $\begin{array}{l}\stackrel{8}{0} \\
\infty \\
\infty\end{array}$ & $\underset{\text { i }}{\text { i }}$ & 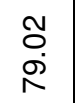 & $\begin{array}{l}\infty \\
0 \\
\oplus\end{array}$ & 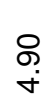 & $\begin{array}{l}\text { o } \\
\infty \\
\infty \\
\infty\end{array}$ & $\underset{\forall}{\stackrel{+}{0}}$ & $\underset{\sim}{\stackrel{\leftrightarrow}{N}}$ \\
\hline
\end{tabular}

For common cold and cough they use Allopathy (44.88\%), Homeopathy (11.11\%), Kabiraji (12\%), Jharfuk (2.22\%) and Bede methods (20.22\%). For fever they also they use Allopathy $(7 \%)$, Homeopathy (4\%), Kabiraji (10.22\%), Jharfuk , $(2.22 \%)$ and bede methods $(39.55 \%)$. For dysenterythe maximum used method is Allopathy (41.77\%). For this disease they also use Homeopathy (24.88\%), Kabiraji (11.11\%), Jharfuk (2.22\%) and Bede methods (16.88\%). For diarrhoea Allopathy is the maximum used method (95.55\%). Other methods are negligible, the percentages of which are Homeopathy $(0.88 \%)$, Kabiraji $(1.77 \%)$, and Jharfuk $(0.88 \%)$. For syphilis and gonnorrhoea treatment the Bede method is the preferred method (35.5\%). Other treatment methods include Allopathy (12.44\%), Homeopathy (12.88) and Kabiraji (29.33\%). For the management of leucoderma, Bede method is used by the maximum number of people (29.33\%). Allopath, Homeopathy, Kabiraji, and Jharfuk are used by $20.44 \%, 14.66 \%, 23.55 \%$ and $3.11 \%$ respectively. For treatment of jaundice they also use Bede methods $(28.00 \%)$ and other methods, such as Kabiraji (26.22\%) and Allopathic (24.88\%). For minor orthopedic cases, they use 
mainly Allopathic method (30.22\%). In this they also go for Bede methods (24.88\%), Jharfuk (6.22\%), Homeopathic (4.88\%) and Kabiraji (20.28\%) treatment. For surgical operation $99.99 \%$ use Allopathic treatment procedure. For treating their complicated diseases Bedes use various methods with different degrees of importance (cf. Table-3b).

\section{Table-2: Social structure and socio-economic conditions of the Bedes}

Bede practitioners are very much popular to the rural peoples of Bangladesh for their specialty in the treatment of some specific diseases like pain, inflammation and arthritis, orchitis, snakebite, nocturnal urination, etc. and for their spiritual treatment of marriage and affairs problems, infertility and psychiatric problems and for removal of "tooth worms". The extent (\%) of various methods used are shown in Table-3b. For the treatment of inflammation, pain and arthritis $44.88 \%$

\begin{tabular}{|c|c|c|c|c|c|c|c|c|c|c|c|c|c|c|c|c|c|c|}
\hline \multicolumn{5}{|c|}{ House structure } & \multicolumn{3}{|c|}{ House No. } & \multicolumn{2}{|c|}{$\begin{array}{c}\text { Family } \\
\text { planning }\end{array}$} & \multicolumn{3}{|c|}{$\begin{array}{l}\text { Vaccine and } \\
\text { vitamin }\end{array}$} & \multicolumn{6}{|c|}{ Recreation status } \\
\hline $\begin{array}{l}\mathbb{J} \\
\mathbb{J} \\
\widetilde{0}\end{array}$ & 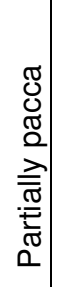 & $\begin{array}{l}\frac{\pi}{\mathcal{J}} \\
\mathbb{\pi} \\
\underline{\underline{\pi}}\end{array}$ & 苄 & $\begin{array}{l}\text { "ृ } \\
\text { ळ }\end{array}$ & 1 & 2 & 3 & $\frac{0}{N^{\pi}}$ & 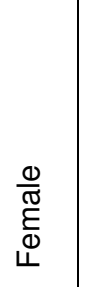 & 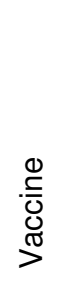 & 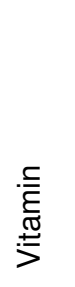 & 言 & $\gtrless$ & 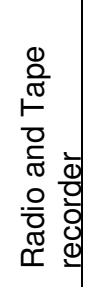 & 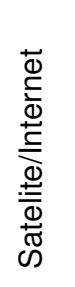 & 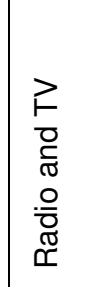 & 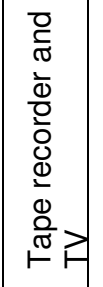 & 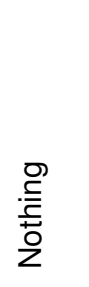 \\
\hline \multicolumn{5}{|c|}{$\%$} & \multicolumn{3}{|c|}{$\%$} & \multicolumn{2}{|c|}{$\%$} & \multicolumn{3}{|c|}{$\%$} & \multicolumn{6}{|c|}{$\%$} \\
\hline $\begin{array}{l}0 \\
m \\
\infty\end{array}$ & $\stackrel{m}{N}$ & 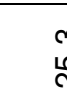 & 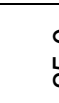 & 인 & $\begin{array}{l}0 \\
\dot{0} \\
\infty\end{array}$ & 요 & 원 & $\begin{array}{ll}9 \\
9 \\
9\end{array}$ & $\begin{array}{l}0 . \\
\dot{0}\end{array}$ & c & $\begin{array}{l}\infty \\
\stackrel{\infty}{\sim} \\
\stackrel{2}{2}\end{array}$ & हैं & 일 & के & 8 & 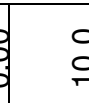 & 9 & $\frac{\circ}{m}$ \\
\hline
\end{tabular}

people use Allopathy, 22.66\%, Homeopathy, $11.11 \%$, Kabiraji, and $4.88 \%$, Jharfuk. However, only $16.44 \%$ of the Bedes have been found to use their own method for treating these diseases. For orchitis, $40.88 \%$ use Allopathy, $15.11 \%$, Homeopathy, $28.00 \%$, Kabiraji, $4.88 \%$, Jharfuk and $11.10 \%$, Bede methods. In case of snake-bite, which is supposed to be their specialty, $59.55 \%$ Bedes use Allopathy, 4.88\%, Homeopathy 9.77\%, Kabiraji, 5.77\%, Jharfuk (5.77\%), and $19.99 \%$, Bede methods. For nocturnal urination Bedes mostly use their own method (29.77\%). Other methods are also used in varying degrees (cf. Table-3b). For marriage and affair problems, 65.33 $\%$ use Bede method. Uses of other methods are not that significant. Treatment of other diseases and problems, as listed in the Table above, are done mainly by the Bede methods. Others are also used in varying degrees of importance (cf. Table-3a). To relive pain, cure arthritis and inflammation Bedes use special method blood-letting, called "Shingalagano", in which they suck out "bad blood" from the body by the use of an animal horn. To aid this system $\mathrm{NaCl}$, mustard oil, bones, and some animal and plant materials, like Oil of snakes, Korpor, Cinnamon, Cardamon, etc) are used. Only $19.6 \%$ have faith in their own method for the treatment of snake-bite. As revealed by the study (Table-3b) $59.6 \%$ cases of the snake-bites are treated by the Allopathic system. Small parts of some selective plants, locally known as turmichandal, burmachandal, swetchandal, are implanted into the skin as a preventive measure from the snake bite. Oral administration of Bede traditional medicines and use of amulets $(29.8 \%)$ are the common practice for diabetic patients or nocturnal urination. For removal of tooth worm from other peoples' teeth, Bedes use cotton, bone of illigiti, root of some plants, chalk powder and incantation or mystical verses. But most of them $(30-50 \%)$ go to the Homeopathic and Allopathic practitioners for the treatment of their dental problems.

Table-3: Hygiene maintenance (Water, Sanitation, Smoking etc)

\begin{tabular}{|c|c|c|c|c|}
\hline Sources of drinking water & $\begin{array}{c}\text { Washing } \\
\text { method }\end{array}$ & Sanitation & $\begin{array}{c}\text { Post toilet hand } \\
\text { washing habit }\end{array}$ & Smoking habit \\
\hline
\end{tabular}




\begin{tabular}{|c|c|c|c|c|c|c|c|c|c|c|c|c|c|c|c|}
\hline 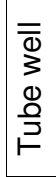 & $\overline{\bar{\Phi}}$ & $\stackrel{\circ}{\stackrel{0}{\oplus}}$ & 응 & $\sum_{\stackrel{\bar{\chi}}{\bar{\nu}}}^{\bar{\lambda}}$ & 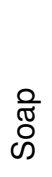 & 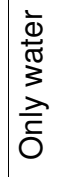 & $\begin{array}{l}\widetilde{J} \\
\text { ర్ } \\
\widetilde{0}\end{array}$ & 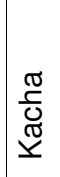 & 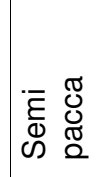 & 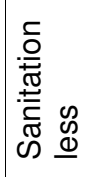 & $\begin{array}{l}\text { वे } \\
\text { कृ } \\
\text { c }\end{array}$ & 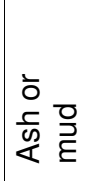 & 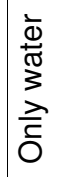 & $\frac{0}{\frac{0}{\pi}}$ & 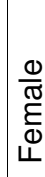 \\
\hline \multicolumn{5}{|c|}{$\%$} & & $\%$ & \multicolumn{4}{|c|}{$\%$} & \multicolumn{3}{|c|}{$\%$} & \multicolumn{2}{|r|}{$\%$} \\
\hline $\begin{array}{l}\text { \& } \\
\text { N }\end{array}$ & $\begin{array}{l}8 \\
\text { டे }\end{array}$ & $\begin{array}{l}8 \\
\infty \\
\infty\end{array}$ & 움 & $\begin{array}{l}8 \\
\infty \\
\infty\end{array}$ & $\begin{array}{l}8 \\
0 \\
\text { in }\end{array}$ & $\begin{array}{l}8 \\
\text { i }\end{array}$ & $\begin{array}{l}\stackrel{9}{0} \\
\stackrel{\sim}{\Omega}\end{array}$ & 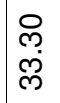 & $\begin{array}{l}R \\
0 \\
\stackrel{N}{N}\end{array}$ & $\begin{array}{l}\stackrel{8}{0} \\
\stackrel{8}{\sigma}\end{array}$ & $\begin{array}{l}\text { \& } \\
\text { ले }\end{array}$ & $\begin{array}{l}8 \\
\dot{q}\end{array}$ & $\begin{array}{l}8 \\
\stackrel{+}{+}\end{array}$ & 竞 & $\begin{array}{l}0 \\
1 \\
0 \\
0\end{array}$ \\
\hline
\end{tabular}

Table -4.a: Treatment methods (\%) received for simple and common diseases management

\begin{tabular}{|l|c|c|c|c|c|c|c|}
\hline $\begin{array}{l}\text { Treatment } \\
\text { Method } \\
\text { Disease Name }\end{array}$ & Allopathy & Homeopathy & Kabiraji & Jharfuk & $\begin{array}{c}\text { Bede } \\
\text { Methods }\end{array}$ & Others & Total \\
\cline { 2 - 8 } & $\%$ & $\%$ & $\%$ & $\%$ & $\%$ & $\%$ & $\%$ \\
\hline Cold and cough & 44.88 & 11.11 & 12.00 & 2.22 & 20.22 & 9.57 & $100.00 \%$ \\
\hline $\begin{array}{l}\text { Fever (Kalajar, } \\
\text { Valokiajar,malaria) }\end{array}$ & 17.13 & 14.00 & 10.22 & 2.22 & 39.55 & 16.88 & $100.00 \%$ \\
\hline Dysentery & 41.77 & 24.88 & 11.11 & 2.22 & 16.88 & 3.14 & $100.00 \%$ \\
\hline Diarrhoea & 95.55 & 0.88 & 0.77 & 0.88 & 1.92 & 0.00 & $100.00 \%$ \\
\hline $\begin{array}{l}\text { Syphilis \& } \\
\text { Gonorrhoea }\end{array}$ & 12.44 & 12.88 & 29.33 & 2.22 & 35.55 & 7.58 & $100.00 \%$ \\
\hline $\begin{array}{l}\text { Leucoderma (White } \\
\text { Leprosy) }\end{array}$ & 20.44 & 14.66 & 23.55 & 3.11 & 29.33 & 8.91 & $100.00 \%$ \\
\hline Jaundice & 24.88 & 8.88 & 26.22 & 4.88 & 28.00 & 7.14 & $100.00 \%$ \\
\hline $\begin{array}{l}\text { Minor orthopedic } \\
\text { case }\end{array}$ & 30.22 & 4.88 & 20.28 & 6.22 & 24.88 & 13.52 & $100.00 \%$ \\
\hline \begin{tabular}{l} 
Surgical operation \\
\hline
\end{tabular} & 100.00 & & 0.00 & & & $100.00 \%$ \\
\hline
\end{tabular}

The bede practioners make the use of crude medicaments and other own spiritual and other types of technique. To relive pain and arthritis they suck out poisoned blood from the body by a method using an animal horn known as shingalagano or roshkhoshani (blood letting). To aid this system Nacl, mustard oil, bones, some animal and plant material (Oil of snakes, Korpor, darochini, elachi, tarpine etc) are used. Only $19.55 \%$ have faith in their own method for the treatment of snakebite. As revealing by the study (Table-4.b) $59.55 \%$ cases of the snakebites are treated by allopathy system. As a preventive measure against the snake bite small parts of some selective plants locally known turmichandal, burmachandal, Setchchandal etc are implanted into the skin (MaleNeck; Female-Arm). Oral administration of Bede traditional medicines and use of amulets (29.8\%) are the common practice for diabetic patients or nocturnal urination. For removal of tooth worm cotton, bone of illigiti, root of some plants, chalk powder and incantation or mystical verse are used in their system. Astonishing that for dental remedies $50 \% \& 30 \%$ people are dependent on Allopathic \& Homeopathy system respectively.

Table-4.b: \% of treatment methods received by Bede people in some complicated diseases:

\begin{tabular}{|l|c|c|c|c|c|c|c|}
\hline $\begin{array}{l}\text { Treatment } \\
\text { method } \\
\text { Diseases Name }\end{array}$ & Allopathy & Homeopathy & Kabiraji & Jharfuk & $\begin{array}{c}\text { Bede } \\
\text { methods }\end{array}$ & Others & Total \\
\cline { 2 - 8 } & $\%$ & $\%$ & $\%$ & $\%$ & $\%$ & $\%$ & $\%$ \\
\hline Pain and Arthritis & 44.88 & 22.66 & 11.11 & 4.88 & 14.22 & 2.25 & 100.00 \\
\hline Orchitis (Ekshira) & 40.88 & 15.11 & 28.00 & 4.88 & 3.55 & 7.58 & 100.00 \\
\hline Snake Bite & 59.55 & 4.86 & 9.77 & 5.77 & 19.55 & 0.50 & 100.00 \\
\hline Nocturnal Urination & 10.22 & 6.22 & 24.88 & 16.88 & 29.77 & 12.03 & 100.00 \\
\hline
\end{tabular}




\begin{tabular}{|l|l|l|l|l|l|l|l|l|}
\hline \multirow{2}{*}{$\begin{array}{l}\text { Spiritual } \\
\text { Treatment }\end{array}$} & $\begin{array}{l}\text { Marriage } \\
\text { affair }\end{array}$ & 00.0 & 00.0 & 9.78 & 10.22 & 65.33 & 14.67 & 100.00 \\
\cline { 2 - 9 } & Infertility & 15.11 & 9.77 & 14.32 & 20.88 & 35.11 & 4.81 & 100.00 \\
\cline { 2 - 9 } & $\begin{array}{l}\text { Psychic } \\
\text { patients }\end{array}$ & 10.66 & 7.55 & 20.00 & 13.77 & 30.66 & 17.36 & 100.00 \\
\hline \multicolumn{2}{|l|}{ Tooth worm } & 50.00 & 30.00 & 10.00 & 3.00 & 5.00 & 2.00 & 100.00 \\
\hline
\end{tabular}

\section{CONCLUSION}

The study revealed that the most people of the Bede community of Bangladesh live a substandard life deprived of most economic and social facilities of modern living. Because of their nomadic nature of living, they remain outside the coverage of development programmes of the Government and thus cannot avail of many of the services provided to the common people of the country by the Government. This is why they suffer from extreme poverty and illiteracy. Their life is full of many abstract and superstitious cultural habits.

\section{REFERENCES}

Beurden, Jos Van (2007), A new research culture for the marginalized in Bangladesh, JIS news letter; 43

Maksud A.K.M (2002), Prospects and possible interactions and potential for Sustainable Development in Bede community, Grameen Trust, Dhaka.

Maksud A.K.M (2006), Participatory actions research for human development for nomadic bede community, Grambangla Unnayan committee and research initiatives, Dhaka, Bangladesh. 